\title{
Influence of Organizational Justice and Job Satisfaction on Teacher's Organizational Citizenship Behavior
}

\author{
Yuyun Elizabeth Patras*, Entis Sutisna \\ Universitas Pakuan \\ Bogor, Indonesia \\ *yuyunpatras64@gmail.com
}

\author{
Muhammad Soleh Afif \\ Madrasah Ibtidaiyah Miftahul Athfal, Tenjolaya \\ Bogor, Indonesia \\ afifkunaefi@gmail.com
}

\begin{abstract}
Organizational Citizenship Behavior (OCB) is an important behavior possessed by teachers. This research aims to analyses the impact of organizational justice and job satisfaction on teacher's OCB. This study was conducted using a sequential explanatory method. The population and sample of this research were Islamic school teachers in Tenjolaya District, Bogor, West Java. Data was directly collected from the participants using questionnaires. The results show that both organizational justice and job satisfaction positively affected teacher's OCB. Organizational justice shows significant correlation on teacher's OCB. Job satisfaction also found do positive correlation with teacher's OCB. Significant correlation also found between organizational justice and job satisfaction. Further, other factors are identified can improve teacher's OCB, including transformational leadership, organizational commitment, organizational culture, and teacher motivation.
\end{abstract}

Keywords: organizational justice, job satisfaction, organizational citizenship behavior

\section{INTRODUCTION}

The basic nature of professional teacher obligations is to carry out tasks and responbilities beyond their main tasks and functions. Anyone who can do that can have an Organizational Citizenship Behavior (OCB). A teacher's OCB can consist of helping co-workers, co-workers who are absent, helping colleagues whose work are overloaded. OCB is very important for organizational progress because it has many beneficial results for the organization and has been considered social capital [1]. OCB agreed by the teachers will make a positive contribution to the efficiency and performance of the school. Teachers with high OCB can contribute maximally to the school [1].

In Indonesian school, teachers with OCB are urgently needed. All-deprived schools need OCB teachers, for example helping schools to carry out extracurricular activities and helping students outside peak hours. In connection with the reality of OCB on teachers, this study will discuss about OCB teachers. This study describes the factors that influence OCB teachers. Many factors influence OCB, while this research focuses on organizational justice and job satisfaction as independent variables.

Organizational Citizenship Behavior (OCB) is the behavior of the extra role of individuals in an organization that is voluntary, free and works beyond the core tasks and explicitly not officially given so as a whole can improve organizational effectiveness, OCB Indicators are: 1). Altruism, 2). conscientiousness, 3). Sportsmanship, 4). Manners, 5). virtue of citizenship [2]. OCB defines as voluntary employee activities at work that may or may not be valued but this OCB's behavior contributes to the organization [3]. Lim and Loosemore states that OCB indicators are as follows: a) doing good work for the organization and its customers, not asking for anything in return b) motivation to continue to improve skills, c) building a climate with high quality performance, trying to improve productivity, and production quality [4].

Behavior in which the lecturer performs his duties and functions beyond what has been described in his work (extra role) on his own awareness to help universities achieve goals with indicators of altruism, sportsmanship, virtue of citizenship, and organizational promoters in education and teaching, research and community service [5]. OCB is voluntary positive behavior that is exhibited by people outside of formal work, and is not related to rewards through the formal system in which organizations are carried out to help organizations towards productivity higher [6]. OCB dimensions include: 1). Altruism 2). Conscientiousness 3). Sportsmanship 4). Civic virtue 5). Tribute. OCB behavior is a behavior carried out by an employee, will greatly help an organization, especially in an educational organization to continue to develop and run well. The scope of OCB behavior carried out by teachers in a school organization includes three behaviors [7]. Based on the theoretical study that has been presented above, it can be synthesized that Organizational Citizenship Behavior (OCB) is good behavior that is done voluntarily by an employee in an organization outside of his main duties without expecting compensation. The indicators are 1). Altruism (Helping co-workers), 2). Sportsmanship (Tolerance to conditions that are less than ideal), 3). Civic virtue (Supports all organizational activities more than personal 
satisfaction are 1). The work itself, 2). Salary, 3). Promotion, 4). Supervision of school principals, 5) Co-workers.

\section{MEthodS}

This research uses mixed methods, which is a combination research method in order to obtain more comprehensive, valid, reliable and objective data [16], with the Sequential Explanatory model, which combines quantitative with qualitative. Quantitative Stage 1). Field facts and data collection, 2). Preliminary Study 3). Problem identification and formulation 4). The foundation of theory, hypothesis, and making research instruments 5). Data collection and analysis 6). Quantitative research results. While the Qualitative stages are: 1). The focus of qualitative research 2). Facts and data in the field 3). Interview instruments, and FGD. 4). Data collection and analysis 5). Qualitative data analysis.

The research was conducted on a sample of 104 permanent teachers of the MI Private Sector Foundation (GTY) in Tenjolaya Sub-District, Bogor Regency with a significance level of research of 0.05 . Based on the method above, this study describes several things that were formulated in the formulation of the research problem, namely: 1). Is there a relationship between organizational justice and Organizational Citizenship Behavior (OCB)? 2). Is there a relationship between job satisfaction with Organizational Citizenship Behavior (OCB)? 3). Is there a relationship between organizational justice and job satisfaction together with Organizational Citizenship Behavior (OCB)? 4). Is one variable higher / dominant than the other? 5). Are there other factors beyond job satisfaction, organizational justice related to Organizational Citizenship Behavior (OCB) in MI in Tenjolaya sub-districts?

\section{RESULTS AND DISCUSSION} satisfaction with the suitability between abilities, skills, and expectations with the work he faces [13].

Job satisfaction is an internal factor that can be considered as an emotional adaptation to work and working conditions. So, if the work is fun for someone, he is satisfied with the work. Conversely, if a person is not fulfilled the job satisfaction he wants, he will not enjoy his work and want to change his job 1). Needs, what level of fulfillment is expected, 2). Individual aspirations, 3). Justice, 4). Genetic component: behavior, attitude, belief in work organization [14].

Job satisfaction is a pleasant or emotionally positive condition that comes from a person's assessment of his work or work experience. The indicators are 1) Pay (salary); financial amount received; 2) Job (working conditions); how far the work gives interesting tasks, 3). Promotion Opportunities (promotional opportunities); possibility to advance in organization; 4) Supervisor (supervisor supervision), 5) CoWorkers (coworkers) [15].

Based on the theories above, it can be synthesized that what is meant by job satisfaction is an employee's attitude towards his work that shows pleasant or unpleasant feelings based on perception, evaluation, and experience. The indicators of job

\section{A. Relationship Between Organizational Justice and Organizational Citizenship Behavior (OCB)}

The results of the study showed that there was a positive relationship between organizational justice and Organizational Citizenship Behavior (OCB), meaning that in an organization, organizational justice was perceived well by the members of the organization, the Organizational Citizenship Behavior (OCB) of the members of the organization would be high. The strength of the relationship between organizational justice and Organizational Citizenship Behavior (OCB) is reflected in the correlation coefficient (ry1) of 0.505 with a regression equation $\hat{\mathrm{Y}}=68,800+0.549 \mathrm{X} 1$. Diversity in Organizational Citizenship Behavior (OCB) which is closely related to organizational justice is reflected in the coefficient of determination (r2) of 0.255 , which is interpreted as $25.5 \%$. Diversity in Organizational Citizenship Behavior (OCB) can be explained by organizational justice while the remaining $74.5 \%$ is influenced by other factors.

Data from the results of qualitative research shows that principals have an open attitude when determining teachers to take part in training outside of school, that is by providing information openly to teachers. Both on social media and at a 
meeting with the teacher council. Teachers who have the desire to attend training will register with the principal, if more than the specified quota the principal will directly appoint the teacher who will be included by selecting teachers, who have not or rarely participated in training. Making the rules carried out by deliberation at the beginning of the year which was attended by foundations, committees, school staff and the teacher council. Rules that are made as much as possible do not harm and benefit one party, but must be neutral.

The principal gives the workload to the teachers seeing from the performance of the previous year. If the performance is good, then the principal will provide the same workload in the previous year or exceed the previous year. Vice versa, if the performance is not good, then the principal might reduce the work of the teacher. The principal treats the teachers well, seen when there is an issue the principal often uses free time, for example during coffee breaks or lunchtime, to interact with subordinates. When interacting, the principal asks the teacher's condition, and the problems that he is facing. Teachers will be more freely to tell their superiors the problems they are facing, so that problems will be easy to overcome.

This treatment is done to all teachers consistently. The words and good behavior of a principal, often felt a good appreciation by the teachers, when the teachers finished doing a job. A teacher who is treated fairly by the school in terms of performance appraisal, management policies and treatment with respect and dignity, will certainly encourage a teacher to maximize his work by working beyond the established requirements. In addition, the headmaster who treats teachers well will increase the teacher's confidence in the organization so that his subordinates will have a tolerance attitude towards the school towards less than ideal conditions. Schools that are fair in determining policies will make teachers more responsible for their assignments and will support all activities in the school. Thus, the organizational reliability of qualitative research in the field has the same tendency with the organizational expertise in qualitative research.

Based on the description above, organizational justice is one of the determining factors in improving Organizational Citizenship Behavior (OCB).

\section{B. Relationship Between Job Satisfaction with Organizational Citizenship Behavior (OCB)}

The results of the study showed that there was a positive relationship between job satisfaction with Organizational Citizenship Behavior (OCB), meaning that in an organization job satisfaction was perceived well by organizational members, Organizational Citizenship Behavior (OCB) of the members of the organization would be high. The strength of the relationship between job satisfaction with Organizational Citizenship Behavior (OCB) is reflected in the correlation coefficient (ry2) of 0.437 with a regression equation $\hat{\mathrm{Y}}=84.807+0.436 \mathrm{X} 2$. Diversity in Organizational Citizenship Behavior (OCB) which is closely related to job satisfaction is reflected in the coefficient of determination ( $\mathrm{r} 2)$ of 0.191 which is interpreted as $19.1 \%$. Diversity in Organizational Citizenship Behavior
(OCB) can be explained by job satisfaction while the remaining $80.9 \%$ is influenced by other factors.

Data from the results of qualitative research show that principals prioritize mutual agreement between teachers, regarding the distribution of teaching schedules, so that teachers will choose the schedule and class based on the ability of the teacher. Financially, Madrasah Ibtidaiyah only relies on BOS funds (School Operational Assistance), which is the time scale for receiving BOS funds, which is three months. Responding to this the principal with various efforts so that the provision of permanent teacher salaries once a month, in a timely manner. Madrasa teachers are known for their "SAJUTA", honest and honest patience. Although salaries are not in accordance with the workload, the lives and finances of teachers are always blessed. As much as possible the school principal completes the facilities and infrastructure for the achievement of learning objectives.

The teacher sees the leader support and give direction to the teachers in learning activities, by discussing in person the problems of the teachers when teaching in class. In general, in a team that is in school, each member always puts the interests of the school over personal interests, this can be seen from the efforts of cooperation that support each other. Satisfaction built by the principal through good communication provides support to teachers in creating good relations between the principal and the teacher and between the teacher and his colleagues in the school, this good relationship will create an attitude of help to help fellow colleagues (Altruism).

Job satisfaction that is built by superiors (principals) by providing good financial services or by providing excellent service, will make teachers support all activities in the school, even teachers will prioritize the interests of the school above other interests. Determination of work in accordance with the potential of the teacher will creat the teacher like his work and make the teacher more responsible.

Thus, job satisfaction in qualitative research in the field has the same tendency with job satisfaction in qualitative research.

\section{Relationship Between Organizational Justice and Job satisfaction with Organizational Citizenship Behavior $(O C B)$}

The results of the study showed that there was a positive relationship between organizational justice and job satisfaction with Organizational Citizenship Behavior (OCB), meaning that in an organization, organizational justice and job satisfaction were perceived well by organizational members, Organizational Citizenship Behavior (OCB) of the members of the organization would be high. The strength of the relationship between organizational justice and job satisfaction with Organizational Citizenship Behavior (OCB) is reflected in the correlation coefficient (ry12) of 0.572 with a regression equation $\hat{Y}=44.526+0.289 \times 1+0.289 \times 2$. Diversity in Organizational Citizenship Behavior (OCB) is closely related to Organizational justice and job satisfaction is reflected in the coefficient of determination (r2) of 0.327 , which means $32.7 \%$ of diversity in Organizational Citizenship Behavior (OCB) can 
be explained by organizational justice and job satisfaction while the remaining $67.3 \%$ is influenced by other factors

Based on the FGD with teachers obtained from the three schools it can be concluded that other factors that also influence the Organizational Citizenship Behavior (OCB) are: a). transformational leadership, b). organizational commitment, c). organizational culture, d). teacher motivation

This current study can be an alternative input for principals and permanent teachers of the foundation (GTY) MI, Tenjolaya District. The order of suggestions for improvement includes: 1). Application of the rules, Principals and organizational management should be fair and consistent in making and implementing an agreed rule. Rules that are made should not be partial or burdensome for some teachers. In the implementation of the principal should not be selective when giving punishment to violating teachers. Rewarding must also be done by the principal for teachers who have high discipline in carrying out a rule. In addition, the headmaster should have a professional nature and take advantage of the opportunity to foster and guide teachers in understanding the school code of conduct, finding and finding new ideas by communicating with teachers, to support the creation of an orderly school environment. 2). Supervision of school principals, principals should conduct supervision activities in schools consistently by making programmatic planning to help the planning planning process. Supervision activities are not an interrogation activity for teachers, but principals should supervise when teachers supervise and guide teachers if there are problems or deficiencies in teachers. So that supervision activities are more efficient and effective.

The results of supervising the headmaster should be transparent, so that the teacher knows his weaknesses and strengths.

In addition, the supervision activities improved the quality of teacher. Principals should make activities such as classroom teacher / subject teacher meetings, internal workshops, and assigning teachers to take part in workshops and educational seminars held by external parties.

\section{CONCLUSION}

According to the results, it can be concluded that: 1). There is a significant positive relationship between organizational justice and Organizational Citizenship Behavior with a correlation coefficient (ry1) of 0.505 with a regression equation $\hat{\mathrm{Y}}=68,800+0.549 \mathrm{X} 1$. The coefficient of determination of 0.255 which means $25.5 \%$ diversity in Organizational Citizenship Behavior (OCB) can be explained by organizational justice. While the remaining $74.5 \%$ is influenced by other factors, the results of qualitative research indicate there is a tendency for the same data between quantitative research and qualitative research. 2). There is a significant positive relationship between job satisfaction with Organizational Citizenship Behavior with a correlation coefficient (ry2) of 0.437 with a regression equation $\hat{\mathrm{Y}}=$ $84.807+0.436$ X2 . Detremination coefficient of 0.191 which means $19.1 \%$ diversity in Organizational Citizenship Behavior
(OCB) can be explained by job satisfaction. While the remaining $80.9 \%$ is influenced by other factors.

The results of qualitative research indicate there is a tendency for the same data between quantitative research and qualitative research. 3). There is a significant positive relationship between organizational justice and job satisfaction with Organizational Citizenship Behavior with a correlation coefficient (ry12) of 0.572 with a regression equation $\hat{\mathrm{Y}}=$ $44.526+0.289 \times 1+0.289 \times 2$. Determination coefficient of 0.327 , which means $32.7 \%$ diversity in Organizational Citizenship Behavior (OCB) can be explained by organizational justice and job satisfaction while the remaining $67.3 \%$ is influenced by other factors. The results of qualitative research indicate there is a tendency for the same data between quantitative research and qualitative research. 4). The results of quantitative and qualitative research show that organizational justice variables are more dominant influential on increasing Organizational Citizenship Behavior (OCB) with a correlation coefficient (ry1) of 0.505 with a regression equation $\hat{\mathrm{Y}}=$ $68,800+0.549 \mathrm{X} 1$. The coefficient of determination of 0.255 means $25.5 \%$. While job satisfaction variables influence the increase in Organizational Citizenship Behavior (OCB) with correlation coefficient (ry2) of 0.437 with a regression equation $\hat{\mathrm{Y}}=84.807+0.436 \mathrm{X} 2$. Determination coefficient of 0.191 which interpreted $19.1 \%$ diversity in Organizational Citizenship Behavior (OCB). 5). The results of qualitative research indicate that there are other factors that also influence or are related to the improvement of Organizational Citizenship Behavior (OCB) including: a). transformational leadership, b). organizational commitment, c). organizational culture, d). teacher motivation.

\section{REFERENCES}

[1] S. Polat, "Organizational citizenship behavior (OCB) display levels of the teachers at secondary schools according to the perceptions of the school administrators," Procedia-Social and Behavioral Sciences, vo. 1, no. 1, pp. 1591-1596, 2009.

[2] A. Rukmini, S. Hadhienata, and R. Retnowati, "The Relationship of Organizational Culture , Transformational Leadership , and Personality to Organizational Citizenship Behaviour ( OCB )," International Journal of Managerial Studies and Research (IJMSR), vol. 5, no. 4, pp. 10-16, 2017.

[3] F. Montani, "Unravelling the relationship between role overload and organizational citizenship behaviour: A test of mediating and moderating effects*," European Management Journal, pp. 1-12, 2018.

[4] B.T.H. Lim and M. Loosemore, "ScienceDirect The effect of interorganizational justice perceptions on organizational citizenship behaviors in construction projects," International Journal of Project Management, vol. 35, no. 2, pp. 95-106, 2017

[5] Y.E. Patras, "Pengaruh Perilaku Kepemimpinan, Keadilan Organisasi Dan Keterlibatan Kerja Terhadap Organizational Citizenzhip Behavior Dosen," Pedagonal| Jurnal Ilmiah Pendidikan, vol. 1, no. 1, pp. 8-14, 2017

[6] A.W. Pourgaz, A.G. Naruei, and H. Jenaabadi, "Examining the Relationship of Organizational Citizenship Behavior with Organizational Commitment and Equity Perception of Secondary School Administrators," Scientific Research Publishing, (May), 800-807, 2015.

[7] D.Z. Mira Ariyani, "Organizational Citizenship Behavior Ditinjau Dari Faktor Demofrafi," Jurnal Penelitian Dan Pengukuran Psikologi, vol. 6, pp. 73-81, 2017. 
[13] S.A. Boamah, H.K.S. Laschinger, C. Wong and S. Clarke, "Effect of transformational leadership on job satisfaction and patient safety outcomes," Nursing Outlook, pp. 1-10, 2017.

[8] J.M. Ivancevich and M.T.M. Robert Konopaske, Organizational Behavior and Management, Seventh Edition. (B. A. Y. Wibi Hardani, Ed.) (7th ed.). Jakarta: Erlangga, 2005.

[9] R.M. Herr, J.A. Bosch, A. Loerbroks, B. Genser, C. Almer, A.E.M. van Vianen and J.E. Fischer, "Organizational justice, justice climate, and somatic complaints: A multilevel investigation," Journal of Psychosomatic Research, vol. 111(November 2018), pp. 15-21, 2018.

[10] H. Kristanto, "Keadilan organisasional, komitmen organisasional, dan kinerja karyawan," Procedia - Social and Behavioral Sciences, vol. 17, no. 1, pp. 86-98, 2015.

[11] R.W.G. Grerory Moorhead, Organizational Behavior: Managing People and Organizations, 9th ed. (D. Angelica, Ed.) (9th ed.). Jakarta: Salemba Empat, 2010.

[12] C. Purpora and M.A. Blegen, "Job satisfaction and horizontal violence in hospital staff registered nurses: the mediating role of peer relationships," Clinical Nursing, vol. 1, no. 415, pp. 2286-2294, 2015.
[14] E.J. Zadeh, R. Talei, A. Shirzadi, A.M. Khatibi, M. Abdolshah, and S. Branch, "Does Job Satisfaction Always Affect Customer Satisfaction? Case Study - ( SSIO ) Social Security Insurance Organization in Tehran," Customer Relationship Marketing and Management, vol. 9, no. 2, pp. 62-78, 2018.

[15] B.S.S. Novita, "Pengaruh Kepuasan Kerja Dan Komitmen Organisasional Terhadap Kinerja Karyawan (Studi pada PT. Telekomunikasi Indonesia, Tbk Witel Jatim Selatan, Malang)," Administrasi Bisnis, vol. 34, no. 1, pp. 38-46, 2016.

[16] J.W. Cresswell, and L.P.C. Vicki, Designing and Conducting Mixed Methods Research. America : Sage Publications, 2007. 